Sakarya Üniversitesi İlahiyat Fakültesi Dergisi

Journal of Sakarya University Faculty of Theology

ISSN: 2146-9806 | e-ISSN: 1304-6535

Cilt/Volume: 23, Sayı/Issue: 43, Y11/Year: 2021 (Haziran/June)

\title{
Selmân b. Rebîa'nın Hayatı ve Faaliyetleri
}

Salmān b. Rabī'a's Life and Activities

\author{
Mücahit Yüksel \\ Doç. Dr., Necmettin Erbakan Üniversitesi Ahmet Keleşoğlu İlahiyat Fakültesi İslam \\ Tarihi Ana Bilim Dalı - Assoc. Prof. Dr., Necmettin Erbakan University, Ahmet \\ Kelesoglu Faculty of Theology, Department of Islamic History \\ myksl_42@hotmail.com \\ https://orcid.org/0000-0003-2958-7813
}

\section{Makale Bilgisi - Article Information}

Makale Türü/Article Type: Araştırma Makalesi/ Research Article

Geliş Tarihi/Date Received: 20/02/2021

Kabul Tarihi/Date Accepted: 18/05/2021

Yayın Tarihi/Date Published: 15/06/2021

Atıf/Citation: Yüksel, Mücahit. "Selmân b. Rebîa'nın Hayatı ve Faaliyetleri”. Sakarya Üniversitesi İlahiyat Fakültesi Dergisi 23/43 (2021), 109-131. https://doi.org/10.17335/sakaifd.883755 .

İntihal: Bu makale, iThenticate yazılımı ile taranmış ve intihal tespit edilmemiştir. Plagiarism: This article has been scanned by iThenticate and no plagiarism detected.

Copyright () Published by Sakarya Üniversitesi İlahiyat Fakültesi - Sakarya University Faculty of Theology, Sakarya/Turkey. 


\section{Selmân b. Rebîa'nın Hayatı ve Faaliyetleri}

Öz

Günümüz dünyası ihtisaslaşma üzerine kurulmuş bir hayata tanıklık etmektedir. Bununla birlikte önceki nesillerin hayatı dikkatli bir şekilde incelendiği takdirde insanların birçok vasfı üzerlerinde taşıdıkları görülmektedir. Hz. Peygamber'in eğitiminden geçen ilk nesil ve onların takipçileri, dinî emirler doğrultusunda çok farklı faaliyetler yürütmüşlerdir. Selmân b. Rebîa'nın hayatı da bu bağlamda güzel bir örnektir. Çünkü o, kendisini sınırlı bir yaşam şekline mahkûm etmemiş ve yeri geldikçe bir hukukçu, bir komutan ve bir ilim adamı olarak faaliyetlerde bulunmuştur. Bir hâkim olarak görev yapan Selmân b. Rebîa aynı zamanda hadis rivayetiyle de meşgul olmuş ve onun hayatı savaş alanında son bulmuştur. Ancak olayları savaş merkezli ele alan tarih anlayışının bir sonucu olarak Selmân b. Rebîa, tarih araştırmalarında hak ettiği ilgiyi yeteri kadar görememiştir. Bu makalede, İslâmî öğretilere dayalı Müslüman yaşamı, Selmân b. Rebîa özelinde ele alınmaktadır. Böylece onun hayatının, diğer yönleriyle de ortaya konulması hedeflenmektedir. Zira hayatın birçok alanında katkılar sunmuş olan bu önemli şahsiyetin, günümüz insanına örneklik teşkil edecek birçok davranışı göze çarpmaktadır.

Anahtar Kelimeler: İslâm Tarihi, Selmân b. Rebîa, Hukuk, İlim, Cihat.

\section{Salmān b. Rab̄̄'a's Life and Activities}

\section{Abstract}

Today's world is witnessing a life based on specialization. However, if the lives of previous generations are examined carefully, it would be seen that people carried diverse qualities. The first generation that had been taught by the Prophet and their followers carried out very different activities in line with religious orders. Salmān b. Rabī'a life is also a good example in this context. Because he did not restrict himself to a limited way of life, and he acted as a jurist, a commander, and a scholar whenever required. Salmān b. Rabī'a, who served as a judge, was also busy with the narration of hadiths, and his life ended on the battlefield. However, as a result an understanding of history that deals with war-centered events, Salmān b. Rabī'a did not get enough attention he deserved in the historical researches. In this article, Muslim life based on Islamic teachings is discussed with specific attention to Salmān b. Rabī‘a. Thus, it is aimed to reveal the other aspects of his life. Because this important personality, who has contributed to many areas of life, draws attention to many behaviors that will set an example for today's people.

[You may find an extended abstract of this article after the references.]

Keywords: Islamic History, Salmān b. Rabī‘a, Law, Science, Jihad.

\section{Giriş}

İslâm, hayatın tüm yönlerine temas eden bütüncül bir yaşam tarzına vurgu yapmaktadır. Bu sebeple ihtisaslaşmaya dayalı günümüz dünyasının aksine geçmiş nesillerin hayatı, genellikle birçok vasfa hâiz insanların varlığına tanıklık etmektedir. Zira Hz. Peygamber, şartların gereği olarak yeri geldiği zaman ticarî faaliyetler yürüten bir insan iken yeri geldiği zaman bir devlet adamı, bir komutan ve eğitmen olarak faaliyetlerde bulunmuştur.

Hz. Peygamber'den aldıkları eğitim istikametinde hayatını sürdüren sahâbe nesli ve onların takipçisi ilk nesiller de aynı doğrultuda bir yaşam sürdüler. Bu çerçevede çalışmamıza konu olan Selmân b. Rebîa'nın (ö. 32/652-653) hayatı da üzerinde durmaya değer güzel örneklerle dolu bir yaşam olmuştur. 
Araştırmalarımız sonucunda Selmân b. Rebîa'nın hayatı ve faaliyetlerine doğrudan temas eden bir çalışmaya rastlamadık. Bu anlamda çalışmamız ilk örneği teşkil edecektir. Bununla birlikte -özellikle- İrminiyye bölgesi fetihleri bağlamında bazı çalışmalarda Selmân b. Rebîa'nın ismi geçmektedir. Bu kapsamda Mevlüt Koyuncu' ${ }^{1}$, Murat Akarsu² ve Fatih Güzel'in ${ }^{3}$ çalışmalarından bahsetmek mümkündür.

Çalışmamızda ilk olarak eldeki veriler doğrultusunda Selmân b. Rebîa'nın hayatı üzerinde durulmaktadır. Ardından onun sahâbî olup olmadığı hususu irdelenmekte ve hukuk, askeriye ve ilim alanlarında yaptığı faaliyetlere temas edilmektedir.

\section{Selmân b. Rebîa'nın Hayatı}

Künyesi "Ebû Abdullah" ${ }^{4}$ olan Selmân b. Rebîa b. Yezîd b. Amr b. Sehm b. Sa'lebe b. Ganm b. Kuteybe b. Ma'n b. Mâlik b. A'sar Abdullah el-Bâhilî̄, Kûfelidir ve Benî Sa'lebe kabilesine mensuptur. ${ }^{6}$ İbn Sa'd (ö. 230/845) onu Kûfe halkının, sahâbe ile çağdaş olan birinci tabakasında zikretmektedir. ${ }^{7}$

1 Mevlüt Koyuncu, “Müslüman Arapların İslam'ın İlk Fetihleri Döneminde İrminiyye ile Olan Münasebetleri", Tarihte Türkler ve Ermeniler: Ortaçă̆ (Ankara: Türk Tarih Kurumu Yayınları, 2014), 2/9-20.

2 Murat Akarsu, "İlk Dönem İslam Tarihinde Yargının Kurumsallaşmasında Dört Halifenin Rolü", Eskiyeni: Anadolu Illahiyat Akademisi Araştırma Dergisi 37 (2018), 57-79.

3 Fatih Güzel, "Ermeniye Fatihi Habib b. Mesleme el-Fihrî'nin Hayatı ve Askeri Faaliyetleri", Türkiye İlahiyat Araştırmaları Dergisi 2/2 (2018), 205-222.

4 Ebu'l-Fadl Ahmed b. Ali b. Muhammed b. Ahmed İbn Hacer el-Askalânî, el-İsâabe fì temyîzi'ṣșahâbe, thk. Âdil Ahmed Abulmevcûd, Ali Muhammed Muavvid (Beyrut: Dâru'l-Kütübi'l'İlmiyye, 1415), 3/117.

5 Ebû Abdullah Muhammed b. Sa'd b. Munî‘ İbn Sa 'd, et-Tabakātü’l-kübrâ, thk. Muhammed Abdülkâdir Atâ (Beyrut: Dâru'1-Kütübi'l-'İlmiyye, 1990), 6/181-182; Ebu'1-Kāsım Ali İbnü'1Hasen b. Hibetullah İbn Asâkir, Târîhu Dımaşk, thk. Amr b. Garâme el-Amravî (Beyrut: Dâru'l-Fikr, 1995), 21/462; İzzüddin İbnü'l-Esîr, Üsdü'l-ġābe fî ma 'rifeti'ṣsṣahâbe, thk. Ali Muhammed Muavvid, Âdil Ahmed Abdulmevcûd (Beyrut: Dâru'l-Kütübi'l-'İlmiyye, 1994), 2/508; Ebu Zekeriyya Muhyiddin Yahya b. Şeref en-Nevevî, Tehzî̉bü'l-esmâ' ve'l-luğāt (Beyrut: Dâru'l-Kütübi'l-‘ilmiyye, ts.), 1/228; Ebü'l-Haccâc Cemâlüddîn Yûsuf b. Abdirrahmân b. Yûsuf el-Mizzî, Tehżîü̈'l-Kemâl fí esmâ'i'r-ricâl, thk. Beşşâr Avad Ma'ruf (Beyrut: Müessesetü'r-Risâle, 1980), 11/240; İbn Hacer el-Askalânî, el-İsâabe, 3/117.

6 Ebû Ömer Yusuf b. Abdullah b. Muhammed İbn Abdilberr, el-İstî 'âb fì ma 'rifeti'l-așhâhb, thk. Ali Muhammed el-Bicâvî (Beyrut: Dâru'l-Cîl, 1992), 2/632; Ebû Bekir Ahmed b. Ali b. Sâbit b. Ahmed b. Mehdî el-Hatîb el-Bağdâdî, Târîhu Bağdâd, thk. Mustafa Abdulkâdir Atâ (Beyrut: Dâru'l-Kütübi'l-'Illmiyye, 1417), 9/204.

7 Ebü'l-Muzaffer Şemsüddîn Yûsuf b. Kızoğlu et-Türkî el-Avnî el-Bağdâdî Sıbt İ̉nü'l-Cevzî̀, Mir 'âtü'z-zamân fì târîhi'l-a yân, thk. Muhammed Berekât vd. (Dımaşk: Dâru'r-Risâleti'l-'Âlemiyye, 2013), 5/459. 
Câhiz'in (ö. 255/869) Kitabu'l-urcân adlı eserinde topal olduğu bilgisi geçen ${ }^{8}$ Selmân b. Rebîa'nın şair ve iyi iz süren bir izci olduğu yönünde bilgiler bulunmaktadır. ${ }^{9}$

Selmân b. Rebîa cesur, erdemli ve âbid bir kahramand1. ${ }^{10}$ Bir sene gazvelere katılıp bir sene hacca gittiği ifade edilmektedir. ${ }^{11} \mathrm{~Hz}$. Ömer (ö. 23/644) tarafından Kûfe kadılığına atanan Selmân b. Rebîa, bu görevden alındıktan sonra Şam ve Irak fetihlerine katıldı. ${ }^{12} \mathrm{~Hz}$. Osman (ö. 35/656) döneminde Türk diyarlarına gazveler düzenledi ve bu kapsamda; Azerbaycan, Errân, Medâin ve Hazar'daki Belencer gazvelerinde yer aldı. Son gazvesi sırasında Belencer'de 32/652 yılında şehit oldu. 28/648, 29/649, 30/650 ve 31/651 yılında şehit olduğu yönünde rivayetler de bulunmaktadır. ${ }^{13}$

Söylendiğine göre onun kemikleri, Belencer halkının yanında bir tabutta bulunmakta idi. Yağmur yağmadığı zaman onu çıkarırlar ve yağmurun yağmasını talep ederlerdi. İbn Cümâne el-Bâhilî bu durumu şiirinde şöyle ifade etmektedir:

Bizim iki kabrimiz vardır: Biri Belencer kabridir...

Bir kabir de Çin'in en yüksek yerlerindedir. Sen ne kabirsin ama!

Şu Çin'dekinin feyz ve yardımı umumidir...

Şu Türk diyarındaki kabrin hürmetine ise yağmurlar yağar.

Çin diyarındaki kabirle kastettiği, Kuteybe b. Müslim’in (ö. 96/715) kabridir. ${ }^{14}$

Bazı tarih kitaplarında, Ömer b. Şebbe ve Ma'bed b. Hâlid el-Cedelî gibi ravilerden rivayet edilen ve Selmân b. Rebîa'nın adının geçtiği bir rivayet bulunmaktadır. Rivayete göre:

Hilafet hakkından feragat eden Hz. Hasan'ın (ö. 49/669) biat etmeyi kabul etmesinden sonra Muâviye b. Ebû Süfyân (ö. 60/680), Ziyâd b. Ebîh'i (ö. 53/673)

8 Kilîc Ebû Abdullah Alâuddin el-Bekcerî, İkmâlu tehzîibi'l-kemâl fî esmâi'r-ricâl, thk. Ebû Abdurrahman Âdil b. Muhammed, Ebû Muhammed Usâme b. İbrahim (Kahire: el-Fârûku'l-Hadîse, 2001), 5/436.

9 Ebû Sa'd Abdulkerim b. Muhammed b. Mansûr et-Temîmî el-Mervezî es-Sem ‘ânî, el-Ensâb, thk. Abdurrahman b. Yahya el-Muallimî el-Yemânî vd. (Haydarabad: Meclisu Dâirati'lMe‘ârif el-'Usmaniyye, 1962), 10/304.

10 Şemsuddin Ebû Abdullah Muhammed b. Ahmed b. Osman b. Kâymâz ez-Zehebî, Târîhu'lİslâm ve vefeyâtü'l-meşâhîr ve'l-a 'âm, thk. Ömer Abdüsselâm et-Tedmurî (Beyrut: Dâru'l-Kitabi'l-'Arabî, 1993), 3/342.

11 İbn Asâkir, Târîhu Dimaşk 21/462.

12 Bağdâdî, Târîhu Bağdâd, 9/204.

13 Ebû Nuaym Ahmed b. Abdullah b. Ahmed b. İshak b. Musa b. Mehrân el-İsfehânî, Ma 'rifetü'ṣ-șahâbe, thk. Âdil b. Yusuf el-Azâzî (Riyâd: Dâru'l-Vatan, 1998), 3/1333; İbn Abdilberr, el-İstî 'âb, 2/633; Bağdâdî, Târîhu Bag்dâd, 9/205; İbn Asâkir, Târîhu Dımaşk, 21/462; İbnü'l-Esîr, Üsdü'l-ḡābe, 2/508.

14 Ebû Muhammed Abdullah b. Müslim b. Kuteybe ed-Dîneverî, el-Ma ârif (Beyrut: Dâru'l-Kütübi'l-'İlmiyye, 2011), 433; Ahmed b. Yahyâb. Câbir b. Dâvûd el-Belâzurî, Fütûhu'l-büldân (Beyrut: Dâru Mektebeti'l-Hilâl, 1998), 202; Sibt İbnü'l-Cevzî, Mir'âtü'z-zamân, 5/459; Zehebî, Târîhu'l-İslâm, 3/342; Salâhuddin Halil b. Aybek b. Abdullah es-Safedî, el-Vâfî bi'l-vefeyât, thk. Ahmed el-Arnaût, Türkî Mustafa (Beyrut: Dâru İhyâi't-Turâs, 2000), 15/193. 
Kûfe'ye gönderdi ve emrini beklemesini söyledi. Ziyâd da Selmân b. Rebîa'nın evine gelerek Muâviye'nin iznini beklemek üzere orada bir süre kaldı. Bu sırada Kûfe valisi olan Muğîre b. Şu'be (ö. 50/670), onun Kûfe valiliği için izin beklediğini zannetti ve Uteybe $b$. Nehhâs el-Aclî'yi yerine vekil birakarak Muâviye'nin yanına gitti. Ona, kendisinin azledilip azledilmediğini sordu. Onun bir sorun çıkarmasından korkan Muâviye ise işine döneceğini söyledi ve fazla bir söz söylemedi. O da Kûfe'ye döndü. ${ }^{15}$

$\mathrm{Bu}$ rivayet, her ne kadar önemli tarih kitaplarında zikredilmiş olsa da nakilci tarih anlayışının bir tezahürü olarak görülmektedir. Zira kaynaklara göre farklı rivayetler bulunmakla birlikte Selmân b. Rebîa'nın, Hz. Osman zamanında vefat ettiği bir gerçektir. Dolayısıyla Muâviye b. Ebû Süfyân'ın Hz. Hasan ile hilafet mücadelesi verdiği 40/661 yılında yaşamış olması muhaldir. Ya da rivayetin doğru olduğu kabul edilmesi durumunda bunun ancak Selmân b. Rebîa'nın vefatından sonra gerçekleştiğini ve Ziyâd'ın onunla yaptığı bir görüşmeyi değil de eskiden onun yaşadığı eve geldiğini ifade ettiğini kabul etmek gerekmektedir.

\section{Selmân b. Rebîa'nın Sahâbîliği Meselesi}

Selmân b. Rebîa'nın sahâbî olup olmadiğı hususunda ulemâ ihtilaf etmiş ve kimi âlimler onun sahâbeden olduğu görüşünü benimserken kimileri tâbiînden olmasını daha muhtemel görmüştür. Hz. Peygamber hayattayken müslüman olması ve bununla birlikte onunla görüştüğüne dâir malumat bulunmaması sebebiyle muhadram olarak kabul edilir. Fakat Hz. Ömer'in sahâbeden olmayan birini ordu komutanlığı ve kadılık görevlerine tayin etmeyeceği yönündeki kanaatlerden hareketle Selmân'ın sahâbî olduğuna dair görüşlere de kaynaklarda yer verilmektedir. ${ }^{16}$

Ebû Nuaym el-İsfehânî (ö. 430/1038) ve İbnü'l-Esîr (ö. 630/1233), Selmân b. Rebîa'nın Hz. Peygamber döneminde yaşadı̆̆ 1 fakat onunla sohbetinin olmadiğı kanaatini paylaşmaktadır. ${ }^{17}$ İclî (ö. 261/875), onun Kûfeli tâbiînin önde gelenlerinden olduğunu ifade etmektedir. ${ }^{18} \mathrm{Onu}$ sahâbe arasında zikreden Buhâri'ye (ö. 256/870) reddiye sadedinde İbn Mende (ö. 395/1005) onun

15 İbn Sa ‘d, et-Tabakāt, 6/181-182; Ebû Hanife Ahmed b. Dâvûd ed-Dîneverî, el-Ahbârü̈'t-tivâl, thk. Abdulmun im Âmir (Beyrut-Kahire: Dâru İhyâi't-Turâsi'l-'Arabî̂-Îsâ el-Bâbî el-Halebî ve Şürekāhu, 1960), 219; Ebû Ca'fer Muhammed b. Cerîr eț-Ṭaberî, Târîhu'l-ümem ve'l-mülûk (Beyrut: Dâru'l-Kütübi'l-'İlmiyye, 1407), 3/196; Sıbt İbnü'l-Cevzî, Mir'âtü'z-zamân, 7747.

16 Abdülkadir Şenel, "Selmân b. Rebîa", Türkiye Diyanet Vakfi İslâm Ansiklopedisi (İstanbul: Türkiye Diyanet Vakfi Yayınları, 2009), 36/443.

17 İsfehânî, Ma 'rifetü'ṣ-șahâbe, 3/1333; İbnü'l-Esîr, Üsdü'l-g̀äbe, 2/508.

18 Ebu'l-Hasen Ahmed b. Abdullah b. Salih el-İclî, Ma 'rifetü's-sikiät min ricâli ehli'l-ilm ve'l-hadis ve mine'd-duafâ ve zikru mezâhibihim ve ahbârihim, thk. Abdulalîm Abdulazîm el-Bistüvî (Medine: Mektebetü'd-Dâr, 1985), 1/422. 
tâbiînden olduğu görüşünü dile getirmektedir. ${ }^{19}$ Muâviye b. Sâlih (ö. 158/775), Yahyâ b. Maîn'in (ö. 233/848), Kûfeli tâbiini sayarken Selmân'1 da zikrettiğini duyduğunu ifade eder. Halife b. Hayyât (ö. 240/854-855) ise tâbiînin birinci tabakasında onu zikreder. ${ }^{20}$ Ayrıca Hatîb el-Bağdâdîn ${ }^{21}$ (ö. 463/1071) ve Nevevî́22 (ö. 676/1277) onun tâbiînden olduğunu ifade eden âlimler arasındadir.

Selmân b. Rebîa'nın tâbiînden olduğunu ifade eden bu grubun karşısında başka bir grup âlim ise onun sahâbî olduğu görüşünü dile getirmektedir. Bu bağlamda Ebû Hâtim (ö. 277/890) onun sahâbî olduğunu söylemektedir. ${ }^{23}$ İbn Abdülber (ö. 463/1071), Ukaylî (ö. 322/934) ve Ebû Hâtim er-Râzî́nin onu sahâbî arasında zikrettiği bilgisini paylaştıktan sonra kendisinin de aynı kanaatte olduğunu ifade etmektedir. ${ }^{24}$ Aynı şekilde Ukaylî ve Ebû Hâtim erRâzî̀ye atıfta bulunan Ebû Ömer el-Kādî'nin (ö. 320/932) yanı sıra ${ }^{25}$ İbn Ebû Hâtim $^{26}$ (ö. 327/938), Zehebî̀ ${ }^{27}$ (ö. 748/1348), Safedîn ${ }^{28}$ (ö. 764/1363) ve İbn Ha$\operatorname{cer}^{29}$ (ö. 852/1449) gibi âlimler de onun sahâbi olduğunu ifade etmişlerdir. Bu konudaki iddiayı bir adım daha ileri götürerek onun Hz. Peygamber'den rivayette bulunduğunu söyleyen âlimler olmuştur. Bu bağlamda Ebû Ubeyd elÂcurrî, Ebû Dâvûd'un (ö. 275/889) onun Hz. Peygamber'den rivayette bulunduğunu söylediğini ifade etmektedir. ${ }^{30} \mathrm{Bu}$ tezi dillendiren âlimlerden biri de İbn Hacer olmuştur. ${ }^{31}$

Bazı âlimler ise Selmân b. Rebîa'nın sahâbî ve tâbiînden olduğu yönündeki görüşleri zikretmekle yetinerek herhangi bir kanaat dile getirmemişlerdir. ${ }^{32}$

Öncelikle ifade etmek gerekir ki Selmân b. Rebîa'nın Hz. Peygamber'den doğrudan hadis rivayet ettiği yönünde görüşler olmakla birlikte, kaynaklarda böyle bir hadise rastlayamadık. Ayrıca onun sahâbeden olduğunu ifade eden

19 Ebû Abdullah Muhammed b. İshâk b. Muhammed b. Yahyâ İbn Mende, Ma 'rifetü'ṣ-ṣahâbe, thk. Âmir Hasan Sabrî (b.y.: Matbûatu Câmi'ati'l-İmârâti'1-'Arabiyyeti'l-Muttehide, 2005), 730; İbnü'l-Esîr, Üsdü'l-g்ābe, 2/508.

20 İbn Asâkir, Târîhu Dımaşk, 21/464.

21 Bağdâdî, Târîhu Bag̀dâd, 9/204.

22 Nevevî, Tehzî̉bü'l-esmâ', 1/228.

23 İbn Asâkir, Târîhu Dımaşk, 21/462; İbn Hacer el-Askalânî, el-İsâabe, 21/466.

24 İbn Abdilberr, el-ístî̀ âb, 2/632.

25 İbnü'l-Esîr, Üsdü'l-ḡābe, 2/508.

26 Ebû Muhammed Abdurrahman b. Muhammed b. İdris İbn Ebî Hâtim er-Râzî, el-Cerh ve'tta 'dîl (Haydarabâd-Beyrut: Dâiratü'l-Me'ârifi'l-'Usmâniyye-Dâru İhyâi't-Turâsi'l-'Arabî, 1952), 4/297.

27 Zehebî, Târîhu'l-İslâm, 2/187.

28 Safedî, el-Vâfî, 15/193.

29 İbn Hacer el-Askalânî, el-İșâbe, 3/117.

30 Mizzî, Tehzîibü'l-Kemâl, 11/242.

31 Ebu'l-Fadl Ahmed b. Ali b. Muhammed b. Ahmed İbn Hacer el-Askalânî, Tehzî̉bü't-Tehzî̉b (Hindistan: Matbaatü Dâiratü'l-Me‘ârif en-Nizâmiyye, 1326), 4/136.

32 Veliyyüddin el-Irâkî Ebû Zür'a, Tuhfetü't-tahsîl fî̀ zikri'l-merâsîl, thk. Abdullah Nevvâre (Riyâd: Mektebetü'r-Rüşd, ts.), 131. 
âlimlerin çoğunluğunun bu bilgiyi kesin bir dille ifade etmek yerine "rivayet edilir" ve "söylenir" gibi tereddüt ifadeleriyle belirttikleri görülmektedir. Yine onun Hz. Peygamber ile görüştügünü delilli bir şekilde ifade eden bir kaynağa rastlanmamaktadır. Bu husustaki ifadelerde sadece onun Hz. Peygamber ile sohbetinin olduğu ifade edilmekle yetinilmiştir. Netice itibariyle cumhurun görüşüne uyarak onun sahâbî değil, Hz. Peygamber döneminde yaşamakla birlikte onunla sohbet etmemiş olan muhadramdan olduğunu kabul etmenin daha uygun olacağı kanaatindeyiz.

\section{Selmân b. Rebîa'nın Faaliyetleri}

Selmân b. Rebîa, hayatı çok yönlü yaşamış ve farklı alanlarda güzel hizmetlerde bulunmuş bir insandır. Zira hayatına dâir verilen bilgiler dikkatlice tetkik edildiği takdirde onun adlî, askerî ve ilmî alanlardaki faaliyetlerinin öne çıktı̆̆1 görülmektedir.

Çalışmamızın bu kısmında, söz konusu başlıklar çerçevesinde Selmân b. Rebîa'nın kadılık görevleri, iştirak ettiği fetih hareketleri ve hadis alanındaki katkıları üzerinde durulacaktır.

\subsection{Adlî Faaliyetleri}

Birçok İslâm tarihi kaynağında Selmân b. Rebîa'nın Hz. Ömer tarafından Kûfe kadılı̆̆ına atandığı, hatta onun Kûfe'nin ilk kadısı olduğu bilgisi geçmektedir. ${ }^{33}$ Ondan sonra Kûfe'nin ikinci kadısı ise Şüreyh (ö. 80/699) olmuştur. Aynı şekilde Kûfe valiliğine atandığı zaman Sa'd b. Ebû Vakkās (ö. 55/675) da onu Kûfe kadılığına atamıştır. ${ }^{34}$

Ebû Bekr el-Hatîb, onun kadılık sürecine tanıklık etmiş olan Ebû Vâil'in (ö. 82/701) şu ifadelerine yer vermektedir:

Ömer İbnü'l-Hattâb tarafından atandıktan sonra Selmân b. Rebîa'nın Medâin'de 40 gün kadılık yapışına tanıklık ettim. Bu süre zarfında onun önüne davalı olarak iki kişinin geldiğine hiç rastlamadım. Kendisine bunun sebebi sorulduğu zaman şöyle dedi: “Çünkü insanlar kendi aralarında insaflı davranmaktaydilar." 35

33 İbn Sa 'd, et-Tabakāt, 6/182; Belâzurî, Fütûhu'l-büldân, 202; Ebû Bekir Muhammed İbnü'l-Hasen b. Düreyd el-Ezdî, el-İştikāk , thk. Abdusselâm Muhammed Harûn (Beyrut: Dâru'l-Cîl, 1991), 273; Muhammed b. Hibbân b. Ahmed b. Hibbân b. Muâz b. Ma‘bed İbn Hibbân, es- $\underline{\text { Sikāt }}$ (Haydarabad: Dâirati'l-Me‘ârifi'l-'Usmâniyye, 1973), 4/332; İbn Mende, Ma 'rifetü'ṣ-șahâhbe, 730; Ahmed b. Ali b. Muhammed b. İbrahim İbn Mencûye Ebû Bekr, Ricâlü Ṣahîhi Müslim, thk. Abdullah el-Leysî (Beyrut: Dâru'l-Ma'rife, 1407), 1/275; İsfehânî, Ma'rifetü'ṣ-șahâbe, 3/1333; Bağdâdî, Târîhu Bağdâd, 9/204.

34 İbn Abdilberr, el-ìstî̀ âb, 2/632.

35 Sibt İbnü'1-Cevzî, Mir'âtü'z-zamân, 5/459; İbn Abdilberr, el-İstî'âb, 2/632; Bağdâdî, Târîhu Bağdâd, 9/204-205; Muhammed b. İsmail b. İbrahim İbnü'l-Muğîre el-Buhârî, et-Târîhu'l-kebîr (Haydarabad: Dâiratü'l-Me‘ârifi'l-'Usmâniyye, ts.), 4/136; Hुalîfe b. Ḩayyât, et-Târîh, thk. Ekrem Ziya el-Umerî (Dımeşk-Beyrut: Dâru'l-Kalem-Müessesetü'r-Risâle, 1397), 155; Ebu'l- 
Rivayetin ilk kısmı her ne kadar Selmân b. Rebîa'nın yanına gelme konusunda insanların çekindiği izlenimini doğuruyor olsa da devamındaki ifade, toplumdaki adalet duygusunun geliştiğini ve insanların çoğu meseleyi kendi aralarında çözecek olgunlukta olduklarını ortaya koymaktadır.

Selmân b. Rebîa, Hz. Ömer zamanında Kādisiye savaşına (15/636) da katılmış ve ordu içerisinde askerî kadı olarak görev yapmıştır. ${ }^{36}$ Ayrıca Mes ‘ûdî (ö. 345/956), onun Hz. Ömer zamanında Medine' de kadılık yaptığına dâir bilgiyi paylaşmaktadır. ${ }^{37}$

\subsection{Askerî Faaliyetleri}

İslâm tarihi kaynaklarında Selmân b. Rebîa'nın ilk askerî faaliyetleri kapsamında, onun Hz. Ömer zamanında Şam'a yönelik icra edilen gaza hareketlerine ve ardından Kādisiye savaşına iştirak ettiğinden bahsedilmektedir. Zira Ebû Üsâme es-Südâ b. Aclân el-Bâhilî ile birlikte Şam'da savaşan ve orada Müslümanların yaptığ ı savaşların çoğuna tanıklık eden Selman b. Rebîa, daha sonra yardım için Kādisiye'ye gönderilenlerle birlikte Irak'a gitmiş ve Kādisiye savaşına iştirak etmiştir. Kardeşi Abdurrahman b. Rebîa (ö. 32/652) ile birlikte süvarilerin başında katıldığı bu savaşta kahramanlıklar gösteren Selmân, Fars ordusunda sancakları altında dikilerek "Bizler öldürülmedikçe buradan ayrılmayız" diyen bir grupla karşılaşmış ve askerleriyle birlikte hücum ederek onları öldürmüşlerdir. ${ }^{38}$

Halep ve Antakya'daki fetih faaliyetlerine komuta eden Ebû Ubeyde b. Cerrâh'ın (ö. 18/639) askerleri arasında yer alan Selmân b. Rebîa, bu esnada sonradan kendi adıyla anılacak olan Kîrus kalesine yerleşmiştir. Günümüzde burası, Hısn Selmân (Selmân Kalesi) adıyla bilinmektedir. ${ }^{39}$

Bizans İmparatoru Herakleios (610-641), 17/638-639 yılında Cezîre halkı tarafından kışkırtıldığı zaman Humus'ta bulunan Ebû Ubeyde komutasındaki Müslümanlara saldırmıştı. Ebû Ubeyde yaptığı istişareler sonunda $\mathrm{Hz}$. Ömer'e mektup yazarak görüşünü almaya karar verdi. Hz. Ömer'in, savaş tekniği açısından önem verdiği bir uygulaması vardı. Buna göre o, tedbir ola-

Kâsım Abdurrahman b. Abdullah b. Ahmed es-Süheylî, er-Ravżü'l-ünüf fi şerhi's -Sîreti'n-nebeviyye li'bni Hişâm, thk. Ömer Abdusselam es-Selâmî (Beyrut: Dâru İhyâi't-Turâsi'l-'Arabî, 2000), 1/134; Cemaluddin Ebu'l-Ferec Abdurrahman b. Ali b. Muhammed İbnü'l-Cevzî, elMuntazam fí târîhi'l-mülûk ve'l-ümem, thk. Muhammed Abdülkadir Atâ, Mustafa Abdülkadir Atâ (Beyrut: Dâru'l-Kütübi'l-'İlmiyye, 1992), 5/6.

36 Dîneverî, el-Ma ârif, 433; Belâzurî, Fütûhu'l-büldân, 202.

37 Ebu'l-Hasen Ali İbnü'l-Hüseyn b. Ali el-Mes' ûdî, et-Tenbîh ve'l-işrâf, thk. Abdullah İsmail esSâvî (Kahire: Dâru's-Sâvî, ts.), 251.

38 Belâzurî, Fütûhu'l-büldân, 255; Țaberî, Târîh, 2/427; Ebü'l-Hasen İzzüddîn Alî b. Muhammed b. Muhammed eş-Şeybânî el-Cezerî İbnü'l-Esîr, el-Kâmil fi't-târîh, thk. Ömer Abdusselam Tedmürî (Beyrut: Dâru'l-Kitabi'l-'Arabî, 1997), 2/314.

39 İbnü'l-Esîr, el-Kâmil, 2/326. 
rak değişik bölgelerde atlılar bulundurmaktaydı. İhtiyaç olması halinde askerler gelir bu atlara biner ve diğer insanlar savaşa hazırlanıncaya kadar bunlar hazır kuvvet olarak yola koyulurlardı. Bu kapsamda Kûfe'de bekletilen birliğin komutasını ise Selmân b. Rebîa yapmaktaydı ve burada 4.000 kadar at bulunmaktaydı. Bu sebeple ona aynı zamanda Selmân el-Hayl adı verilmiştir. Ebû Ubeyde'nin mektubunun ardından Hz. Ömer, Sa'd'a haber göndererek Kā'b. Amr'ı (ö. 40/660) destek olarak Humus'a göndermesini istedi. ${ }^{40}$ Selmân b. Rebîa'nın atlar konusundaki uzmanlığını anlatmak için şöyle denirdi: "O, hayvanın mafsallarını, onu kesen kasaptan daha iyi bilen kişidir." 41

Ayrıca Sa'd b. Ebû Vakkās tarafından Medâinlilerin üzerine gönderilen orduda ganimetlerin paylaştırılması işine başkanlık etmekle görevlendirilen Selmân, -Kisrâ'nın sarayındakiler de dâhil olmak üzere- bütün ganimetleri toplatarak, kaçanların takibi sonucu getirilen ganimetlerin hepsini tespit etmiş ve görevini başarılı bir şekilde icra etmiştir. ${ }^{42}$

Selmân b. Rebîa' nın Hz. Ömer döneminde katıldı ğı diğer bir askerî faaliyet 22/642-643 yılında gerçekleştirilen Bâbu'l-Ebvâb’ın fethi olmuştur. Buraya gönderilen askerlerin öncülerinin kumandanlı̆̆ına Abdurrahman b. Rebîa'yı atayan Hz. Ömer, ordunun sol ve sağ kanatlarına Bükeyr b. Abdullah el-Leysî (ö. ?) ile Hüzeyfe b. Esîd el-Gıfârî'yi (ö. 42/662) tayin ederken, ganimetlerin paylaştırılması görevini de Selmân b. Rebîa'ya vermişti. ${ }^{43}$

Hz. Ömer'in emrettiği şekilde ilerleyen ordu Bâb'a vardığı zaman İrminiyye Kralı Şehrebzâr'ın haber gönderip eman talep etmesi üzerine Abdurrahman b. Rebîa ona eman verdi. Ardından Habîb b. Mesleme (ö. 42/662), Surâka b. Amr (ö. 30/650), Bükeyr b. Abdullah el-Leysî, Selmân b. Rebîa ve Huzeyfe b. Esed (ö. ?) İrminiyye çevresindeki Tiflis, Lân ve Mugān dağlarında yaşamakta olan insanların üzerine gönderildi. Bu süreçte Bükeyr, Mugān'ı fethetti. Müslümanların komutanı olan Surâka b. Amr'ın vefat etmesi üzerine Abdurrahman b. Rebîa komutayı devraldı ve Hz. Ömer bunu onayladı. Hz. Ömer'in, Türk diyarına doğru hareket etmesini emreden mektubu geldiği zaman Abdurrahman harekete geçti ve ardından Belencer üzerine birçok akın düzenledi. ${ }^{44}$

Hz. Ömer'in vefatının ardından hilafete geçen Hz. Osman döneminde de Selmân b. Rebîa, kardeşi Abdurrahman b. Rebîa ile birlikte fetih faaliyetlerini

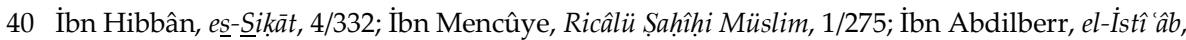
2/632; Süheylî, er-Ravżü'l-ünüf, 1/134; İbnü'l-Esîr, el-Kâmil, 2/355; İbnü'l-Esîr, Üsdü'l-ġābe, 2/508; Mizzî, Tehżîü'l-Kemâl, 11/241.

41 Țaberî, Târîh, 2/427.

42 İbnü'l-Esîr, el-Kâmil, 2/342.

43 Țaberî, Târîh, 2/540; İbnü'1-Esîr, el-Kâmil, 2/410; Ebu'l-Fidâ İsmail b. Ömer el-Kuraşî İbn Kesîr, el-Bidâye ve'n-nihâye, thk. Abdullah b. Andulmuhsin et-Türkî (Kahire: Dâru Hicr, 1997), 7/139.

44 Ṭaberî, Târîh, 2/540; İbn Kesîr, el-Bidâye, 7/139. 
sürdürdü ve Türk illerine yapılan gaza faaliyetleri sırasında Abdurrahman b. Rebîa' nın şehit olmasının ardından sancağı alarak mücadelelere devam etti. ${ }^{45}$

Hz. Osman'ın halifeliği döneminde Kûfe valiliğine getirilen Velîd b. Ukbe (ö. 61/680-681), Azerbaycan ve İrminiyye üzerine seferlere çıtı̆̆1 zaman Selmân b. Rebîa'yı öncü kuvvet olarak görevlendirdi. 4 bin askerin başında komutan olarak gönderdiği Abdullah b. Şübeyl (ö. ?) ise; Mugān, Bebr ve Teylesân üzerine akınlar düzenledi. Ardından Velîd b. Ukbe, Azerbaycan halkıyla 800 bin dirhem ödemeleri şartıyla antlaşma yaptı. Daha önce 22/642-643 yılında Hüzeyfe b. el-Yemân'ın (ö. 36/656) antlaşma yaptığı bu zümre, Hz. Ömer'in vefatının ardından söz konusu antlaşmayı bozmuştu. Abdullah, bu akınlardan bol miktarda ganimet elde ederek döndüğü zaman Velîd, 25/645 yılında Selmân b. Rebîa'yı 12 bin askerle birlikte İrminiyye üzerine gönderdi. Aynı şekilde Selmân da büyük başarılar elde etti ve çok miktarda ganimet ele geçirdi. ${ }^{46}$

Bizanslıların büyük bir ordu topladıkları haberini alan Hz. Osman, Velîd b. Ukbe'ye haber göndererek Kûfe halkından 8/9 ya da 10 bin kişilik orduyu takviye birlik olarak göndermesini istedi. Bunun üzerine Velîd, Selman b. Rebîa'yı 8 bin kişilik orduyla birlikte gönderdi. Rûm topraklarına hücum eden bu ordu, çok sayıda kaleyi ele geçirdi. ${ }^{47}$ Olayın seyri şu şekilde gelişmiştir: Hz. Osman, halife olduğu zaman Şam valisi Muâviye b. Ebû Süfyân'a bir mektup yazdı ve onun, Habîb b. Mesleme el-Fihrî' yi İrminiyye' ye göndermesini emretti. Şam fetihleri ve Bizans savaşlarında güzel işler başarmış birisi olan Habîb’in kahramanlığını hem Hz. Ömer hem de Hz. Osman çok iyi biliyordu. ${ }^{48} \mathrm{~Hz}$. Osman'dan gelen emirle birlikte Muâviye b. Ebû Süfyân, Habib b. Mesleme' yi çağırdı ve yanına 4 bin atlı ile 2 bin yaya asker vermek suretiyle İrminiyye üzerine yürümesini emretti. Bunun üzerine o, önce Cezîre topraklarına ardından da İrminiyye üzerine yürüdü. ${ }^{49}$ Ancak daha doğru kabul edilen başka bir rivayete göre ise Hz. Osman mektubu, Muâviye b. Ebû Süfyân'a değil doğrudan Habîb'e yazdı. Bunun üzerine Şam ve el-Cezîre halkından olan 6 veya 8 bin askerle hareket eden Habîb, Kâlîkalâ'ya geldi. Şehir halkı ilk etapta direniş gösterince aralarında savaş çıkmışsa da ardından onlar, şehri terk etmek veya cizye ödemek şartıyla eman istediler. Bunun üzerine içlerin-

45 İbnü'l-Esîr, el-Kâmil, 2/412.

46 Țaberî, Târîh, 2/592; Şemseddin Ebû Abdullah Muhammed b. Ahmed b. Osman b. Kaymâz ez-Zehebî, el- 'íber fi haberi men ġaber, thk. Ebû Hacer Muhammed es-Saîd b. Besyûnî Zağlûl (Beyrut: Dâru'l-Kütübi'l-‘ìlmiyye, ts.), 1/20; Hüseyin b. Muhammed İbnü'l-Hasen ed-Diyârbekrî, Târîhu'l-hamîs fí ahvâli enfesi nefís (Beyrut: Dâru Sâdır, ts.), 2/255.

47 İbnü'l-Cevzî, el-Muntazam, 4/345.

48 Belâzurî, Fütûhư'l-büldân, 196.

49 Ebû Muhammed Ahmed İbn Asem el-Kûfî, Kitâbü'l- Fütûh, thk. Ali Şînî (Beyrut: Dâru'l-Evdâ, 1991), 2/341. 
den birçoğu şehri terk etti ve Bizans topraklarına sığındı. Sonra Müslümanlara karşı Patrik Ermenyakos'un liderliğinde büyük bir ordu hazırlandı̆̆ gisi alınd1. ${ }^{50}$ Muâviye'nin talebi üzerine Hz. Osman, Velîd'e haber göndererek ehliyetine güvendiği bir komutanla birlikte 8-10 bin asker göndermesini istedi. ${ }^{51}$

Hz. Osman'ın mektubu geldiği zaman Velîd b. Ukbe Allah Teâlâ'ya hamdu senâ ettikten sonra insanlara hitaben şöyle bir konuşma yaptı:

Ey insanlar! Halife Osman b. Affân'dan bir mektup geldi. Bu mektubunda o, Selmân b. Rebîa el-Bâhilî komutasında 10 bin kişilik askerî birliği Şimşât (Samsat) topraklarındaki kardeşlerinize yardımcı olarak göndermemi emrediyor. Zira Rûmlar onlara karşı büyük bir ordu toplamıştır. Bunda büyük bir ecir ve sevap vardır...

Bunun üzerine kimse cihattan geri kalmak istemedi ve bu orduya iştirak etti. Bu noktada Kûfeliler ile Şamlılar arasında yaşanmakta olan rekâbete işaret eden bir rivayet aktarılmaktadır. Söz konusu rivayete göre;

Kûfe halkının bu tutumu Habîb'e ulaştığı zaman o, yanındaki adamlarına şöyle dedi: "Yazıklar olsun size ey Şam halkı! Size yardım, Kûfelilerden geldi. Korkarım düşmana karşı zafer elde edilmesi halinde sizin değil de onların başarısından bahsedilecek. İsterseniz Kûfeliler yanımıza gelmeden önce düşmanla çarpışmaya girelim." Buna karşılık onlar: "Karar sana aittir, dilediğini yap, biz sana uyarız" dediler. Bunun üzerine Habîb b. Mesleme, geceleyin askerleriyle birlikte düşmana hücum etti ve birçoğunu öldürürken çoğunu da esir aldı. Şamlı askerler, elde ettikleri çok sayıda ganimeti kendi aralarında paylaştıktan sonra Kûfeli askerlerle birlikte Selmân b. Rebîa geldi ve ganimetlerden pay isteyerek şöyle dedi: "Bu ganimetlerden bize de verin; zira siz, bizim gelmemiz sebebiyle cesaret kazandınız ve düşmana karşı bu şekilde galip geldiniz." 52

İki birlik arasında yaşanan anlaşmazlık öyle tehlikeli boyutlara ulaştı ki; taraflar birbirilerine yönelik ağır sözler söylemeye başladılar, hatta Şamlılardan bazıları Selman'ı ölümle tehdit ettiler. Bu tehdide cevap mahiyetinde Kûfeliler ise şu şiirle cevap verdiler: "Ĕ̆ger Selmân'ı öldürürseniz biz de Habîb'inizi öldürürüz / Ĕ̆ger İbn Affân'a doğru giderseniz biz de gideriz." 53

Aralarında bu şekilde çatışmaya varacak derecede söz düellosu devam ederken ve birbirilerini tehdit etmektelerken Habîb b. Mesleme Iraklılara haber göndererek, "Kardeşlerinizle savaşma konusunda aceleci davranmayın,

50 Belâzurî, Fütûhu'l-büldân, 196.

51 Taberî, Târîh, 2/592; Ebû Muhammed Ali b. Ahmed b. Saîd b. Hazm el-Endelüsî, Cevâmi 'u'ssîre ve hamsü resâ' ile uhrâ, thk. İhsan Abbâs (Misır: Dâru'l-Me'ârif, 1900), 343; İbnü'1-Esîr, elKâmil, 2/457.

52 İbn Asem el-Kûfî, el-Fütûh, 2/342.

53 Belâzurî, Fütûhu'l-büldân, 197, 279; İbn Asem el-Kûfî, el-Fütûh, 2/343; Ebû Abdullah Muhammed b. Abdullah b. Muhammed Hâkim en-Nîsâbûrî, el-Müstedrek ale'ṣ-Ṣahîhayn, thk. Mustafa Abdulkadir Atâ (Beyrut: Dâru'1-Kütübi'1-'İlmiyye, 1990), 3/389; Ahmed b. el-Hüseyn b. Ali b. Mûsâ Ebû Bekr el-Beyhakī, es-Sünenü'l-kübrâ, thk. Muhammed Abdülkādir Atâ (Beyrut: Dâru'l-Kütübi'l-'İlmiyye, 2003), 6/545. 
durumu halifeye yazalım" dedi. Onlar da bu öneriyi kabul ettiler. Muâviye b. Ebû Süfyân aracılığıyla durumu bildiren mektup Hz. Osman'a gönderildi. Durum Hz. Osman'a haber verilince o, ganimetlerin Şam halkının hakkı olduğunu yazd1. ${ }^{54}$ Ancak başka bir rivayete göre Hz. Osman bu ganimetlerden Irak halkına da pay verilmesini emretti ve bunun üzerine onlara payları verildi. ${ }^{55}$

Daha sonra birlikte fetih faaliyetleri yürütüldü. Habîb b. Mesleme bir koldan fetih faaliyetlerini icra ederken, diğger taraftan Selmân b. Rebîa, Errân üzerine yürüyüp Beylekān kalesini sulh yoluyla ele geçirdi. Ardından Berzea üzerine yürüyen Selmân, bir nehir kenarında bulunan Sursûr bölgesinde karargâh kurdu. Halkıyla günlerce süren çarpışmanın ardından bu bölge sulh yoluyla ele geçirildi. Aynı zamanda tebliğ faaliyetleri de icra eden Selmân, Belâşcân Kürtlerini İslâm'a davet etti. Fakat bu davetine olumlu karşılık alamadı ve kendisine karşı koyarak çarpışan bu zümre mağlup olunca içlerinden bir kısmı cizye, bir kısmı da zekât vermeyi kabul etti. Sonra faaliyetlerini sürdüren Selmân, Erez ve el-Kürr nehirlerinin birleştiği yere gelerek Kabale şehrini fethetti, Seker ve diğer şehirlerin halkıyla bazı vergiler ödemek üzere anlaşma yaptı. Aynı şekilde Şirvan ile birlikte diğer dağlık bölgelerin hükümdarlarının yanı sıra Maskat, eş-Şâberan ve Bâb el-Ebvâb şehirlerinin halklariyla da sulh yaptı. ${ }^{56}$

Fetih faaliyetleri kapsamında birçok önemli işe imza atan Selmân b. Rebîa, Belencer Irmağı'nın arkasında yapılan savaşta 4 bin Müslüman asker ile birlikte şehit oldu. ${ }^{57}$ Onun şehit oluşuna dâir rivayetlerde olayın oluş şekli özetle şöyle anlatılmaktadır: Fetih faaliyetlerini başarılı bir şekilde icra etmekte olan Selmân b. Rebîa, 300 bin askere komuta eden Hazar Hakanının bulunduğu Bâb'a gitti. Fakat onlar, Araplarla savaşmayı göze alamadılar ve hemen şehri terk ettiler. Hakan'nın bu cesaretsizliğinin arka planında, Araplar hakkında duyduğu bazı söylentilerin rolünün olduğu görülmektedir. Zira maiyetinde bulunan komutanlar ona: "Senin yanında 300 bin asker bulunmakta, onlar ise 10 bin askerden oluşmaktadır. Bu büyük orduyla onlara yenilecek misin?" dedikleri zaman onun: "Duyduğuma göre onlar gökyüzünden inmişler ve silah onlara zarar vermiyormuş; hâl böyleyken onların karşısında kim durabilir?" diye cevap verdiği rivayet edilmektedir. ${ }^{58}$ Fakat bu sırada onların bilgilerinin yanlışlığını öğrenmelerine sebep olacak bir olay yaşandı. Selmân b. Rebîa komutasındaki askerler Belencer' de konakladıkları esnada Hakan'ın askerlerinden biri Müslüman askerlerden birini nehir kenarında gördüğü zaman onlar hakkındaki bilginin doğruluğunu test etmek istedi ve okunu çıkararak onu

54 Hâkim en-Nîsâbûrî, el-Müstedrek, 6/545.

55 İbn Asem el-Kûfî, el-Fütûh, 2/343.

56 Belâzurî, Fütûhu'l-büldân, 201-202; İbnü'l-Esîr, el-Kâmil, 2/459.

57 Belâzurî, Fütûhu'l-büldân, 202.

58 İbn Asem el-Kûfî, el-Fütûh, 2/344; İbn Kesîr, el-Bidâye, 7/140. 
öldürdü. Ardından başını keserek Hakan'a getirdi ve onun önüne koyduktan sonra: "İşte silahın etki etmediğini söylediğin adam" dedi. Bunun üzerine cesaret kazanan Hakan, askerlerini toplayarak Müslümanlarla savaşmaya karar verdi. Savaş sonunda Müslümanlar ağır bir yenilgi aldı ve askerlerin hepsi öldürüldü. Selmân b. Rebîa da askerleriyle birlikte bu savaşta şehit oldu. Bu askerlerin Belencer'de bulunan kabirleri meşhurdur ve günümüze kadar onların bu kabirleri Şehitlerin kabirleri diye anılmaya devam etmiştir. ${ }^{59}$

Görünen o ki; Araplar hakkında Türkler arasında yaygın olan efsanevî inanış, onların Araplardan çekinmesine ve mücadeleden kaçmalarına sebep olmuştur. Ancak onların öldürülebileceklerine dâir edindikleri tecrübe sonucunda bakış açılarının değişmesiyle birlikte savaşın seyri de değişmiştir. Ancak bununla birlikte söz konusu inanışın etkilerinin tam olarak atılamadığı ve Araplara saygı duyma şeklinde tezahür etmeye devam ettiği görülmektedir. Kanaatimizce Selmân b. Rebîa'nın cesedinin saklanıp yağmur duasında kullanılmasinın altında yatan sebep budur.

\section{3. İlmî Faaliyetleri}

Selmân b. Rebîa, ilim alanında da hizmetler vermiş ve bazı rivayetlerin bize kadar ulaşmasına katkıda bulunmuştur. Kaynaklarda onun, fazla hadis rivayet etmediği ifade edilmektedir. ${ }^{60}$ Sika bir ravi olan Selmân b. Rebîa, hadisçilerin güvendiği bir şahsiyet olmuştur. ${ }^{61}$

Kaynaklarda, Selmân b. Rebîa'nın Hz. Peygamber'den doğrudan naklettiği bir hadise rastlayamadık. Onun rivayetleri genellikle Hz. Ömer'den yapılmıştır. ${ }^{62}$ Selmân b. Rebîa'dan nakilde bulunan raviler ise; Adî b. Adî (ö. ?), Subey b. Ma'bed (ö. ?), Ebû Vâil Şakīk b. Seleme (ö. 82/701), Dabî İbnü'lMa‘bed (ö. ?), Amr b. Meymûn (ö. 74/693), Ebû Osmân en-Nehdî (ö. 100/718) ve Berâ b. Kays'tır (ö. ?). ${ }^{63}$

Selmân b. Rebîa'nın en meşhur rivayeti Hz. Ömer'den yaptığı şu nakildir: Osman b. Ebû Şeybe-Züheyr b. Harb-İshâk b. İbrahim el-Hanzalî-Cerîr-A'meşEbû Vâil ve Selmân b. Rebîa tarikiyle rivayet edildiğine göre Ömer b. el-Hattâb şöyle dedi: “Hz. Peygamber bir taksimatta bulundu. Ardından ben: 'Ey Allah'ın Rasûlü! Vallahi bunların dışındakiler ona daha layıktırlar' dedim. Bunun

59 İbn Asem el-Kûfî, el-Fütûh, 2/345; İbnü'1-Esîr, el-Kâmil, 2/503.

60 İbn Sa'd, et-Tabakāt, 6/182; Nevevî, Tehzî̉bü'l-esmâ', 1/228; Mizzî, Tehż̂̉bü'l-Kemâl, 11/241; İbn Hacer el-Askalânî, Tehzî̉bü't-Tehzî̉b, 4/136.

61 İbn Sa'd, eț-Tabakāt, 6/182; İclî, Ma 'rifetü's-sikiāt, 1/422; Bağdâdî, Târîhu Bag̀dâd, 9/205; Nevevî, Tehżîü̈l-esmâ', 1/228; Mizzî, Tehżîü̈'l-Kemâl, 11/241; İbn Hacer el-Askalânî, Tehżîuü't-Tehzî̉b, $4 / 136$.

62 İbn Sa'd, et-Tabakāt, 6/182; Bağdâdî, Târîhu Bağdâd, 9/204; İbn Asâkir, Târîhu Dımaşk, 21/462; Sibt İbnü'l-Cevzî, Mir 'âtü'z-zamân, 5/459.

63 İbn Hibbân, eś-Sikiāt, 4/332; İbn Mende, Ma rifetü'ṣ-șahâhe, 730; İbn Mencûye, Ricâlü Șahîhhi Müslim, 1/275; İ̀sfehânî, Ma 'rifetü'ș-șahâbe, 3/1333; İbn Abdilberr, el-İstî̀âb, 2/633; Bağdâdî, Târîhu Bağdâd, 9/204; İbnü'l-Esîr, Üsdü'l-ġābe, 2/508; Zehebî, Târîhu'l-İslâm, 3/342. 
üzerine Hz. Peygamber: ‘Onlar fâhiş bir şekilde benden istemek veya cimrilik yapmak arasında beni serbest bırakırlar. Oysa ben cimri değilim’ buyurdu.” 64

Söz konusu bu rivayetin muhtevası başka kaynaklarda, Hüseyn b. İshâk et-Tüsterî-Yahyâ b. Osman-İbn Himyer-İbrahim b. Muhammed-Süleyman elA'meş-Şakîk-Selmân b. Rebîa tarikiyle de gelmektedir ve Selmân b. Rebîa tarafından sanki Hz. Peygamber'i görmüş izlenimi verecek şekilde anlatılmakta olan bu rivayette Hz. Ömer' in sözünden içerik olarak bahsedilmektedir. ${ }^{65} \mathrm{Ka}$ naatimizce Selmân b. Rebîa'nın sahâbi olup olmadığı konusunda yaşanan ihtilafta bu rivayetin etkisi bulunmaktadır. Ancak Müslim'in rivayetindeki senede göre o, bu rivayeti Hz. Ömer'den nakletmektedir. Ayrıca diğer rivayetin yine Hz. Ömer'den nakledilmekle birlikte farklı ifadeyle telaffuz edilme ihtimali göz ardı edilemez.

Bu rivayetin dışında, Selmân b. Rebîa'nın naklettiği veya onunla ilgili olarak nakledilen başka rivayetler de bulunmaktadır:

Süleyman b. Harb-Şu'be-Seleme b. Küheyl tarikiyle gelen rivayete göre Süveyd b. Gafele şöyle dedi:

Bir gazvede Selmân b. Rebîa ve Zeyd b. Sûhân ile birlikteydim. Hemen bu esnada bir kırbaç buldum. Bunun üzerine ikisi bana, onu atmamı söylediler. Ben bunu kabul etmedim ve: "Hayır; Sahibini bulursam ona veririm, aksi takdirde ondan faydalanırım." dedim. Döndügüümüz zaman karşılıklı delillerle tartıştık ve Medine'ye vardığım zaman durumu Übey b. Ka'b'a sordum. Bunun üzerine o şöyle dedi: “Hz. Peygamber zamanındayken içinde yüz dinar bulunan bir kese buldum ve hemen Hz. Peygamber'e getirdim. Hz. Peygamber: ‘Onu bir yıl süreyle ilan et' dedi. Bir yıl süreyle ilanettikten sonra Hz. Peygamber'e tekrar geldim. 'Onu bir yıl ilan et' dedi. Bir yıl süreyle ilan ettikten sonra tekrar yanına geldim. Tekrar 'Onu bir yıl ilan et' dedi. Bir yıl ilan ettikten sonra dördüncü kez onun yanına geldim. Bu kez şöyle dedi: ‘Onun sayısını, ağzının bağını ve kabını belle. Sahibi gelirse teslim edersin, gelmezse ondan istifade edersin.' "66

Lukata (buluntu mal) ile ilgili bu rivayete göre Selmân b. Rebîa'nın, böyle bir malın kullanımına karşı çıktığı görülmektedir. Ancak Übey b. Ka'b’ı bu konuda yaşadığg tecrübe ve Hz. Peygamber'den aldığg bilgi, onun bu görüşünün yanlışlı̆̆ını ortaya koymaktadır.

64 Müslim b. el-Haccâc Ebu'l-Hasen el-Kuşeyrî, el-Müsnedü's-sahîhi'l-muhtasar bi-nakli'l-adli ani'l-adli ilâ Rasûlillah (s.a.v.), thk. Muhammed Fuâd Abdulbâkî (Beyrut: Dâru İhyâi't-Turâsi'l'Arabî, ts.), 2/730 (1056).

65 “Bir gün Hz. Peygamber bir taksimatta bulundu. Hemen ardından Ömer b. Hattâb: ‘Ey Allah'ın Rasûlü! Vallahi bunların dışındakiler -Suffe ehli- ona daha layıktırlar' dedim. Bunun üzerine Hz. Peygamber: 'Onlar fâhiş bir şekilde benden istemek veya cimrilik yapmak arasında beni serbest bırakırlar. Oysa ben cimri değilim' buyurdu." bk. Ebu'l-Hüseyn Abdülbâkî b. Kāni ‘ b. Merzûk b. Vâsık İbn Kāni', Mu 'cemü'ṣ-șahâhe, thk. Salâh b. Sâlim el-Misrâtî (Medine: Mektebetü'l-Gurabâi'l-Eseriyye, 1418), 1/286; İbn Asâkir, Târîhu Dımaşk, 21/462.

66 Ebû Abdullah Muhammed b. İsmail el- Buhârrî, Șahîhu'l-Buhârî̀ (Dımaşk-Beyrut: Dâru İbn Kesîr, 2002), “Lukata”, 10 (2437). 
Yine Selmân b. Rebîa'nın nakletmediği ancak içeriğinde zikredildiği bir başka rivayet şu şekildedir:

Muhâmmed b. Kudâme b. A'yen-Osman b. Şeybe el-Ma'nâ-Cerîr b. Abdülhamîd-Mansûr ve Ebû Vâil tarikiyle gelen rivayete göre Subey b. Ma'bed şöyle anlatmaktadır: "Hıristiyan bedevî bir adamdım ve Müslüman oldum. Aşiretimden Huzeym b. Sürmüle adında bir adama geldim ve ona: 'Ey adam! Ben cihad etmek istiyorum ve hac ile umrenin üzerime vacip olduğunu görüyorum. Bu ikisini (hac ve umre) nasıl yapabilirim?' dedim. O da dedi ki: 'İkisini birleştir ve kolayına gelenden hedy kurbanını kes.' Ben de bu şekilde yaptım. Sonra ben bu halde Uzeyb'e geldiğim zaman Selmân b. Rebîa ve Zeyd b. Sûhân ile karşılaştım. Birbirilerine bakarak: 'Bu adam, devesinden daha fakih değil.' dediler. O anda sanki üzerime bir dağ atılmış gibi oldum ve Ömer b. el-Hattâb'ın yanına gelerek: 'Ey Mü'minlerin emiri! Ben, Hıristiyan bedevî bir adamdım ve Müslüman oldum. Cihad yapmak istiyorum ve hac ile umrenin de bana gerekli olduğunu gördüm. Kavmimden bir adama gelip sorduğum zaman bana: 'Íkisini birleştir ve kolayına gelenden hedy kurbanını kes' dedi. Ben de bu şekilde yaptım.' dedim. Bunun üzerine o bana: 'Peygamber'in (s.a.v.) sünnetine uymuşsun' dedi." 67

Ebû Ömer b. Hayeveyh-Yahyâ-Hüseyn-Abdullah-Süfyân-İshâk-Mürre ve Amr b. Şurahbîl tarikiyle gelen şu rivayet de Selmân b. Rebîa'nın, kadılığı sırasında verdiği bir cevap üzerinedir. Buna göre:

Şüreyh'den önce kadı olan Selmân b. Rebîa'ya bir fariza hakkında soruldu. O da cevabında hata etti. Bunun üzerine Amr b. Şurahbîl: "Meselenin aslı şu şekildedir" diye açıklamada bulundu. Selmân da ona kızdı. Durum, Kûfe valisi Ebû Mûsâ el-Eş'arî’ye iletildi. Ebû Mûsâ: "Selmân! Kızmaman gerekirdi, ayrıca ey Amr! Senin de onu kulağına söylemen gerekirdi." dedi. ${ }^{68}$

Buna göre Selmân b. Rebîa, bir konuda verdiği yanlış bir cevabın insanlar önünde alenen düzeltilmesi şeklindeki üslûba kızmaktadır. Kûfe valisi Ebû Mûsâ el-Eş‘arî ise olayda dengeli bir tutum sergileyerek, onu sükûnete davet etmekte, kızdığı kişiyi de bu tür uyarıları gizlice yapması gerektiği konusunda uyarmaktadir.

Abdurrezzâk-İbn Uyeyne-Âsım b. Süleyman ve Ebû Osman en-Nehdî tarikiyle gelen şu rivayette ise Selmân b. Rebîa vasıtasıyla fıkhî bir hüküm öğrenmekteyiz:

Ebû Osman en-Nehdî dedi ki: “Selmân b. Rebîa'yı Ömer'i dinlerken gördüm. Ardından bir konu hakkında ona soru sordu. Bunun üzerine biz ona: 'Ne sor-

67 Ebû Abdullah Ahmed b. Muhammed b. Hanbel b. Hilal b Esed eş-Şeybânî Ahmed b. Hanbel, Müsnedü'l-İmâm Ahmed b. Hanbel, thk. Şuayb el-Arnaût vd. (Beyrut: Müessesetü'r-Risâle, 2001), 1/365-366; Ebû Abdurrahman Ahmed b. Şuayb b. Ali en-Nesâ̂, el-Müctebâ mine's-sünen, thk. Abdulfettâh Ebû Gudde (Halep: Mektebetü'l-Matbûâti'l-İslâmiyye, 1986), 5/147.

68 Ebû Abdurrahman Abdullah İbnü'l-Mübârek, Kitâbü'z-Zühd ve'r-rekā'ik, thk. Habîburrahman el-A'zamî (Beyrut: Dâru'l-Kütübi'l-‘ìlmiyye, ts.), 233. 
dun?' dediğimiz zaman şu şekilde cevap verdi: 'Karısıyla bir ilişkide bulunduktan sonra ikinci kez ilişkide bulunmak isteyen kişinin ne yapması gerektiği hususunu sordum, o da: 'İkisinin arasında abdest alır' dedi." 69

Yahyâ b. Saîd el-Kattân-Süfyân-Rukeyn ve babası tarikiyle gelen şu rivayet, Selmân b. Rebîa'nın fetihler sırasında komuta ettiği ordunun Belencer'de konaklaması esnasında verdiği bir fetvaya işaret etmektedir: "Belencer'de Selmân b. Rebîa ile birlikteydik. Bu esnada ben, 29. gecenin ardından 30 . günde Şevvâl hilalini gördüm. Selman, bunu kendisine göstermemi istedi. Ona gösterdikten sonra insanlara emretti ve onlar da iftar ettiler."70

Sevrî-Câbir ve Âmir'den nakledilen rivayete göre Selmân b. Rebîa'ya, bir adamdan bakmak üzere bir malı satın alan, fiyatı belirleyen ve bu esnada ölen kişi hakkında soruldu. O da cevaben, bu malın fiyatının ödeneceğini söyledi. ${ }^{71}$

Ma 'mer-Abdurrahman ve Kâsım b. Abdurrahman'dan nakledilen şu rivayet de Selmân b. Rebîa'nın verdiği bir fetvanın İbn Mes‘ûd tarafından düzeltildiğine işaret etmektedir:

Bir adam, üzerinde sahibi varken onun bineğini dehledi. Bunun üzerine o da gitti ve bir başkasını yaraladı. Ardından Selmân b. Rebîa'ya gelip durumu sordular. $\mathrm{O}$, binek üzerindeki adamın tazminat ödemesi gerektiğini söyledi. Ardından İbn Mes'ûd'a gittiler. O ise bineği dehleyen kişinin tazminat ödemesi gerektiğini söyledi. ${ }^{72}$

Saîd-İsmail b. Ayyâş-Haccâc ve Ebû İshâk tarikiyle gelen rivayete göre Selmân b. Rebîa şöyle demiştir: "Müşrikler, Müslümanlardan birinin bir malını alırsa ve sonra onlara galip gelindiği zaman o mal paylaşılmamışsa sahibinindir. Eğer paylaşılmışsa artık onun onda hakkı yoktur." 73

Saîd-İsmail b. Ayyâş-Haccâc b. Ertât ve Kâsım b. Muhammed tarikiyle gelen rivayete göre, Selmân b. Rebîa Belencer'e sefer düzenlediği zaman, müşrik olan insanlardan da yardım istedi. Buna gerekçe olarak ise "Allah düşmanlarını Allah'ın başka düşmanlarına karşı teşvik ettiğini” söyledi. ${ }^{74}$

Abde-A'meş ve Şakîk tarikiyle rivayet edildiğine göre Selmân b. Rebîa şöyle demiştir: "Ömer b. el-Hattâb, yatsı namazından sonra gece sohbeti yapmamızı doğru bulmazdı." 75

69 Ebû Bekr Abdurrezzâk b. Hemmâm b. Nâfi ‘ el-Himyerî Abdurrezzâk b. Hemmâm, el-Muṣannef, thk. Habîburrahman el-A'zamî (Beyrut: el-Mektebü'l-İslâmî, 1403), 1/276. Ebû Bekir b. Ebû Şeybe Absî, Abdullah b. Muhammed b. İbrahim b. Osman b. Havâstî, el-Kitâbü'l-Mușannef fi'l-ehâdîs ve'l-âsârr, thk. Kemal Yusuf el-Hût (Riyâd: Mektebetü'r-Rüşd, 1409), 1/79.

70 Abdurrezzâk b. Hemmâm, el-Mușannef, 4/163. Absî, el-Kitâbü'l-Mușannef, 5/562.

71 Abdurrezzâk b. Hemmâm, el-Mușannef, 8/54; Absî, el-Kitâbü'l-Mușannef, 4/507.

72 Abdurrezzâk b. Hemmâm, el-Mușannef, 9/422; Absî, el-Kitâbü'l-Mușannef, 5/458.

73 Ebû Osman Saîd b. Mansûr b. Şu ‘be el-Horasânî el-Cûzcânî Sa 'īd b. Manșūr, Sünenü Sa ìd b. Manșūr, thk. Habîburrahman el-A'zamî (Hindistan: ed-Dâru's-Selefiyye, 1982), 2/335.

74 Manșūr, Sünenü Sa ìd b. Manșūr, 2/383.

75 Absî, el-Kitâbü'l-Muṣannef, 2/78. 
Abdullah b. İdris-Babası ve Hakem tarikiyle rivayet edildiğine göre, Abdullah cenaze namazı kıldıracakken Selmân b. Rebîa geldi. Bunun üzerine Abdullah ona: "Öne geç ve kardeşinin namazını kıldır" dedi. ${ }^{76}$

Abdullah b. İdris, babası ve amcasından şu rivayeti aktarmaktadır: “Selmân b. Rebîa: 'Şu kılıcımla, Allah'tan başkasına ibadet eden yüz kişiyi, hiçbirini esir almadan ve hapse atmadan öldürdüm.' dedi."77

Ebû Usâme-İbn Cüreyc-Hârûn b. Ebû Âişe ve Adî b. Adî tarikiyle gelen rivayete göre Selmân b. Rebîa şöyle anlatmaktadır:

Ömer b. el-Hattâb: “Emirlerin ve işçilerin bir araya gelip sohbet etmeleri fitne, ayrılmaları küfür olacak." dedi. Bunun üzerine ben: "Allahu Ekber! Tekrar eder misin ey Mü'minlerin emiri! Beni rahatlattın.” dedim. Sonra Ömer onu tekrar ettiği zaman şöyle dedim: "Fitne bana öldürmekten daha sevimlidir. Hâlbuki Yüce Allah şöyle buyurmuştur: 'Fitne, öldürmekten daha kötüdür'”' (el-Bakara $2 / 191)^{78}$

Muhammed el-Müsenna-Muâz b. Hişâm-Katâde ve Abdullah b. Büreyde tarikiyle gelen son rivayet de Selmân b. Rebîa'nın Abdullah b. Amr ile görüşmesinden bahsetmektedir. Buna göre Selmân b. Rebîa şöyle dedi:

Yanımdakilerle birlikte yola çıtık ve Mekke'ye geldik. Orada Abdullah b. Amr ile görüşmek istedik; fakat onu bulamadık. Sonra üç yüze yakın yolcuyla birlikte geri döndük ve camide onunla görüştük. Bir de ne görelim; üzerinde mutevazi bir elbise ve başında bir sarık vardı ama gömlek yoktu. "Siz kimlerdensiniz?" dedi. Irak halkından olduğumuzu söyleyince: “Ey Irak halkı! Yalan söylüyorsunuz! Yalan söylüyorsunuz! Alay ediyorsunuz!" dedi. Biz de: "Yalan söylemiyoruz! Yalan söylemiyoruz! Alay etmiyoruz!" dedik. Ardından: “Eyle ile aranızda ne kadar var?" diye sordu. "Dört fersah olduğunu" söyledik. Bunun üzerine şöyle dedi: "Kandûra b. Kerkeroğulları nerdeyse sizi Horasan ve Sicistan'dan sert bir şekilde atmak üzere. Sonra çıkacaklar ve atlarını Dicle nehrine bağlayacaklar. Onlar; küçük gözlü, kalkık burunlu ve yüzleri sanki dövülmüş kalkan gibi geniş bir topluluktur." 79

Görüldüğü üzere Selmân b. Rebîa, gerek ordu komutanlığı, gerek kadılığı ve gerekse günlük hayatı sırasında kendisine getirilen bazı meseleler hakkında fetva vermiş, bazen de bizzat kendisi Hz. Ömer'e sorular yöneltmiştir. Elbette verdiği bazı fetvalarda hata etmesi insanî bir durumdur. Ancak genel anlamda o, Hz. Ömer'e sorduğu sorular ya da kendisine sorulduğu zaman verdiği cevaplarla ilim alanında da önemli hizmetler vermiş bir şahsiyettir.

76 Absî, el-Kitâbü'l-Muṣannef, 3/41.

77 Absî, el-Kitâbü'l-Mușannef, 4/219.

78 Absî, el-Kitâbü'l-Mușannef, 7/458.

79 Ahmed b. Ali b. Abdulkādir Takiyuddin el-Makrîzî, İmtâ 'u'l-esmâ ' bimâ li'r-resûl mine'l-ebnâ'i ve'l-ahvâl ve'l-hafede ve'l-metâ', thk. Muhammed Abdülhamid en-Nemîsî (Beyrut: Dâru'l-Kütübi'l-'İlmiyye, 1999), 12/310. 


\section{Sonuç}

Yüce Allah Kur'ân-1 Kerim' de şöyle buyurmaktadır: "İşlerini kendi aralarında parça parça ettiler. Her grup kendinde bulunan ile sevinmektedir." (el-Mu'minûn 23/53.) Malesef günümüz dünyasında Müslümanların da içine düştükleri acı bir gerçektir bu. Zira İslâm'ın tüm hayatı kuşatan hakikatlerine muhatap olan Müslüman toplumda, bu hakikatler istikametinde yürüyen ilk nesillerin aksine parça parça edilmş bir hayatın farklı cüzlerini sahiplenmiş ve hayatı sadece bir yönüyle yaşama sığlığına düşmüş, hatta çoğu zaman da diğer cüzleri sahiplenen Müslümanlara hasmane duygular besleyen insanlara tanıklık edilmektedir. Hâlbuki Selmân b. Rebîa özelinde temas etmeye çalıştığımız İslâmî pratik, Müslüman hayatının; ilim, cihat ve meslek anlamında bir bütün olarak değerlendirilmesi en azından birbirilerine rakip unsurlar olarak görülmemesi gerektiğini güzel bir şekilde ortaya koymaktadır. Bu bağlamda ifade etmek gerekirse; İslâm'da anlatılan Müslüman hayatı, mümkün olan her alanda dine hizmet etmeyi hedefleyen bir pratiği yansıtmalıdır. Bu çerçevede bir hayat yaşayan Selmân b. Rebîa'nın salih amellerle geçen ve şehitlikle taçlanan ömrü, günümüz Müslümanları için güzel bir örneklik teşkil etmektedir.

Selmân b. Rebîa, Hz. Peygamber dönemine yetişmiş bir şahsiyet olmakla birlikte -sahâbî olduğuna dâir bazı görüşler bulunsa da- elde ettiğimiz veriler ışığında onun Hz. Peygamber ile görüştüğünü söylemek mümkün görünmemektedir. Zira onun faaliyetlerine dâir bilgilerin Hz. Ömer döneminden itibaren görülmeye başlaması ve Hz. Peygamber döneminde hiçbir askerî ve sosyal faaliyette adının geçmemesi de bunu destekelmektedir.

Hz. Ömer döneminde kadılık görevi icra eden Selmân b. Rebîa daha sonra fetih faaliyetlerine katılmıştır. Kaynaklardaki bilgiler onun daha çok Türk bölgelerine yönelik faaliyetlerde bulunduğunu göstermektedir. Ayrıca bu bilgiler arasında Türklerin Araplara bakışını yansıtan önemli anekdotlar da bulunmaktadır. Zira Türklerin onları gökten gelen ve öldürülmesi mümkün olmayan varlıklar olarak gördükleri ve bu sebeple savaşmaktan çekindiklerine dâir bilgi önemli bir hususu ifade etmektedir.

Hz. Ömer ile daha çok sohbet gerçekleştirdiği dikkat çeken Selmân b. Rebîa'nın, onun vasıtasıyla bazı hadisler rivayet ettiği görülmektedir. Çok fazla rivayeti bulunmayan Selmân b. Rebîa, genel olarak muhaddisler tarafından, tâbiînden sika bir ravi olarak görülmektedir. 


\section{Kaynakça}

Abdurrezzâk b. Hemmâm, Ebû Bekr Abdurrezzâk b. Hemmâm b. Nâfi“ el-Himyerî. elMușannef. thk. Habîburrahman el-A'zamî. 11 Cilt. Beyrut: el-Mektebü'l-İslâmî, 2. Basim, 1403.

Absî, Ebû Bekir b. Ebû Şeybe, Abdullah b. Muhammed b. İbrahim b. Osman b. Havâstî. el-Kitâbü'l-Mușannef fi'l-ehââîs ve'l-âsâr. thk. Kemal Yusuf el-Hût. 9 Cilt. Riyâd: Mektebetü'r-Rüşd, 1409.

Ahmed b. Hanbel, Ebû Abdullah Ahmed b. Muhammed b. Hanbel b. Hilal b Esed eşŞeybânî. Müsnedü'l-İmâm Aḥmed b. Hanbel. thk. Şuayb el-Arnaût vd. 50 Cilt. Beyrut: Müessesetü'r-Risâle, 2001.

Akarsu, Murat. “Illk Dönem İslam Tarihinde Yargının Kurumsallaşmasında Dört Halifenin Rolü". Eskiyeni: Anadolu İlahiyat Akademisi Araştırma Dergisi 37 (2018), 5779.

Bağdâdî, Ebû Bekir Ahmed b. Ali b. Sâbit b. Ahmed b. Mehdî el-Hatîb. Târîhu Bağdâd. thk. Mustafa Abdulkâdir Atâ. 24 Cilt. Beyrut: Dâru'l-Kütübi'l-'İlmiyye, 1417.

Bekcerî, Kilîc Ebû Abdullah Alâuddin. İkmâlu tezhîbi'l-kemâl fî esmâi'r-ricâl. thk. Ebû Abdurrahman Âdil b. Muhammed, Ebû Muhammed Usâme b. İbrahim. 12 Cilt. Kahire: el-Fârûku'l-Hadîse, 2001.

Belâzurî, Ahmed b. Yahyâ b. Câbir b. Dâvûd. Fütûhu'l-büldân. Beyrut: Dâru Mektebeti'l-Hilâl, 1998.

Beyhakī, Ahmed b. el-Hüseyn b. Ali b. Mûsâ Ebû Bekr. es-Sünenü'l-kübrâ. thk. Muhammed Abdülkâdir Atâ. 24 Cilt. Beyrut: Dâru'l-Kütübi'l-'İlmiyye, 3. Basım, 2003.

Buhârî, Ebû Abdullah Muhammed b. İsmail. Șahîhụu'l-Buhârî. Dımaşk-Beyrut: Dâru İbn Kesîr, 2002.

Buhârî, Muhammed b. İsmail b. İbrahim İbnü'l-Muğîre. et-Târîhu'l-kebîr. 8 Cilt. Haydarabad: Dâiratü'l-Me'ârifi'l-'Usmâniyye, ts.

Dîneverî, Ebû Hanife Ahmed b. Dâvûd. el-Abbârü'ț-țtvâl. thk. Abdulmun im Âmir. Beyrut-Kahire: Dâru İhyâi't-Turâsi'l-'Arabî-Îsâ el-Bâbî el-Halebî ve Şürekāhu, 1960.

Dîneverî, Ebû Muhammed Abdullah b. Müslim b. Kuteybe. el-Ma 'ârif. Beyrut: Dâru'lKütübi'l-'Illmiyye, 3. Basım, 2011.

Diyârbekrî, Hüseyin b. Muhammed İbnü'l-Hasen. Târîhu'l-hamîs fî ahvâli enfesi nefîs. 2 Cilt. Beyrut: Dâru Sâdır, ts.

Ebû Zür'a, Veliyyüddin el-Irâkî. Tuhfetü't-tahsîl fî̀ zikri'l-merâsîl. thk. Abdullah Nevvâre. Riyâd: Mektebetü'r-Rüşd, ts.

Endelüsî, Ebû Muhammed Ali b. Ahmed b. Saîd b. Hazm. Cevâmi 'u's-sîre ve hamsü resâ'ile uhrâ. thk. İhsan Abbâs. Misır: Dâru'l-Me'ârif, 1900.

Ezdî, Ebû Bekir Muhammed İbnü'l-Hasen b. Düreyd. el-İstikāk. thk. Abdusselâm Muhammed Harûn. Beyrut: Dâru'l-Cîl, 1991.

Güzel, Fatih. “Ermeniye Fatihi Habib b. Mesleme el-Fihrî’nin Hayatı ve Askeri Faaliyetleri". Türkiye İlahiyat Araştırmaları Dergisi 2/2 (2018), 205-222.

Hâkim en-Nîsâbûrî, Ebû Abdullah Muhammed b. Abdullah b. Muhammed. el-Müstedrek 'ale'ș-Șahîhayn. thk. Mustafa Abdulkadir Atâ. 4 Cilt. Beyrut: Dâru'l-Kütübi'l-'ilmiyye, 1990.

Halîfe b. Hayyâț. et-Târîh. thk. Ekrem Ziya el-Umerî. Dımeşk-Beyrut: Dâru'l-KalemMüessesetü'r-Risâle, 2. Basım, 1397. 
İbn Abdilberr, Ebû Ömer Yusuf b. Abdullah b. Muhammed. el-İstî̀ âb fî ma 'rifeti'l-așhâab. thk. Ali Muhammed el-Bicâvî. 4 Cilt. Beyrut: Dâru'l-Cîl, 1992.

İbn Asâkir, Ebu'l-Kāsım Ali İbnü'l-Hasen b. Hibetullah. Târîhu Dımaşk. thk. Amr b. Garâme el-Amravî. 80 Cilt. Beyrut: Dâru'l-Fikr, 1995.

İbn Asem el-Kûfî, Ebû Muhammed Ahmed. Kitâbü'l-Fütûh. thk. Ali Şîrî. 9 Cilt. Beyrut: Dâru'l-Evdâ, 1. Basım, 1991.

İbn Hacer el-Askalânî, Ebu'l-Fadl Ahmed b. Ali b. Muhammed b. Ahmed. el-İsâbe fî temyîzi'ṣ-șahâbe. thk. Âdil Ahmed Abulmevcûd, Ali Muhammed Muavvid. 8 Cilt. Beyrut: Dâru'l-Kütübi'l-'Illmiyye, 1415.

İbn Hacer el-Askalânî, Ebu'l-Fadl Ahmed b. Ali b. Muhammed b. Ahmed. Tehzî́bü'tTehzî̉b. 12 Cilt. Hindistan: Matbaatü Dâiratü'l-Me'ârif en-Nizâmiyye, 1326.

İbn Hibbân, Muhammed b. Hibbân b. Ahmed b. Hibbân b. Muâz b. Ma'bed. eś- Sikāt. 9 Cilt. Haydarabad: Dâirati'1-Me'ârifi'l-'Usmâniyye, 1973.

İbn Kāni', Ebu'l-Hüseyn Abdülbâkî b. Kāni' b. Merzûk b. Vâsık. Mu 'cemü'ș-șahâbe. thk. Salâh b. Sâlim el-Misrâtî. 3 Cilt. Medine: Mektebetü'l-Gurabâi'l-Eseriyye, 1418.

İbn Kesîr, Ebu'l-Fidâ İsmail b. Ömer el-Kuraşî. el-Bidâye ve'n-nihâye. thk. Abdullah b. Andulmuhsin et-Türkî. 21 Cilt. Kahire: Dâru Hicr, 1997.

İbn Mencûye, Ahmed b. Ali b. Muhammed b. İbrahim Ebû Bekr. Ricâlü Ṣahîhi Müslim. thk. Abdullah el-Leysî. 2 Cilt. Beyrut: Dâru'l-Ma'rife, 1407.

İbn Mende, Ebû Abdullah Muhammed b. İshâk b. Muhammed b. Yahyâ. Ma 'rifetü'ṣșahâhbe. thk. Âmir Hasan Sabrî. b.y.: Matbûatu Câmi'ati'l-İmârâti'l-'Arabiyyeti'lMuttehide, 2005.

İbn Sa'd, Ebû Abdullah Muhammed b. Sa'd b. Munî'. eț-Ṭabakātü'l-kübrâ. thk. Muhammed Abdülkâdir Atâ. 8 Cilt. Beyrut: Dâru'l-Kütübi'l-'İlmiyye, 1990.

İbnü'l-Cevzî, Cemaluddin Ebu'l-Ferec Abdurrahman b. Ali b. Muhammed. el-Muntazam fî târîhi'l-mülûk ve'l-ümem. thk. Muhammed Abdülkadir Atâ, Mustafa Abdülkadir Atâ. 19 Cilt. Beyrut: Dâru'l-Kütübi'l-'İlmiyye, 1992.

İbnü'l-Esîr, Ebü'l-Hasen İzzüddîn Alî b. Muhammed b. Muhammed eş-Şeybânî el-Cezerî. el-Kâmil fi't-târîh. thk. Ömer Abdusselam Tedmürî. 10 Cilt. Beyrut: Dâru'lKitabi'l-'Arabî, 1997.

İbnü'l-Esîr, İzzüddin. Üsdü'l-ġābe fî ma 'rifeti'ș-șahâbe. thk. Ali Muhammed Muavvid, Âdil Ahmed Abdulmevcûd. 8 Cilt. Beyrut: Dâru'l-Kütübi'l-'İlmiyye, 1994.

İbnü'l-Mübârek, Ebû Abdurrahman Abdullah. Kitâbü'z-Zühd ve'r-rekā'ik. thk. Habîburrahman el-A'zamî. Beyrut: Dâru'l-Kütübi'l-'İlmiyye, ts.

İclî, Ebu'l-Hasen Ahmed b. Abdullah b. Salih. Ma'rifetü's-sikenat min ricâli ehli'l-ilm ve'lhadis ve mine'd-duafâ ve zikru mezâhibihim ve ahbârihim. thk. Abdulalîm Abdulazîm el-Bistüvî. 2 Cilt. Medine: Mektebetü'd-Dâr, 1985.

İsfehânî, Ebû Nuaym Ahmed b. Abdullah b. Ahmed b. İshak b. Musa b. Mehrân. Ma rifetü'ṣ-șahâbe. thk. Âdil b. Yusuf el-Azâzî. 7 Cilt. Riyâd: Dâru'l-Vatan, 1998.

Koyuncu, Mevlüt. “Müslüman Arapların İslam'ın İlk Fetihleri Döneminde İrminiyye ile Olan Münasebetleri”. Tarihte Türkler ve Ermeniler: Ortaçă̆. 2/9-20. Ankara: Türk Tarih Kurumu Yayınları, 2014.

Kuşeyrî, Müslim b. el-Haccâc Ebu'l-Hasen. el-Müsnedü's-sahîhi'l-muhtasar bi-nakli'l-adli ani'l-adli ilâ Rasûlillah (s.a.v.). thk. Muhammed Fuâd Abdulbâkî. 5 Cilt. Beyrut: Dâru İhyâi't-Turâsi'l-'Arabî, ts. 
Makrîzî, Ahmed b. Ali b. Abdulkādir Takiyuddin. İmtâ'u'l-esmâ' bimâ li'r-resûl mine'lebnâ'i ve'l-ahvâl ve'l-ḥafede ve'l-metâ'. thk. Muhammed Abdülhamid en-Nemîsî. 15 Cilt. Beyrut: Dâru'l-Kütübi'l-'İlmiyye, 1999.

Mes 'ûdî, Ebu'l-Hasen Ali İbnü'l-Hüseyn b. Ali. et-Tenbîh ve'l-işrâf. thk. Abdullah İsmail es-Sâvî. Kahire: Dâru's-Sâvî, ts.

Mizzî, Ebü'l-Haccâc Cemâlüddîn Yûsuf b. Abdirrahmân b. Yûsuf. Tehżîbü'l-Kemâl fî esmâ'i'r-ricâl. thk. Beşşâr Avad Ma'ruf. 35 Cilt. Beyrut: Müessesetü'r-Risâle, 1980.

Nesâî, Ebû Abdurrahman Ahmed b. Şuayb b. Ali. el-Müctebâ mine's-sünen. thk. Abdulfettâh Ebû Gudde. 8 Cilt. Halep: Mektebetü'l-Matbûâti'l-İslâmiyye, 2. Basım, 1986.

Nevevî, Ebu Zekeriyya Muhyiddin Yahya b. Şeref. Tehzî̉ü'l-esmâ' ve'l-luġāt. 4 Cilt. Beyrut: Dâru'l-Kütübi'l-'İlmiyye, ts.

Râzî, Ebû Muhammed Abdurrahman b. Muhammed b. İdris İbn Ebî Hâtim. el-Cerh ve't-ta 'dîl. 9 Cilt. Haydarabâd-Beyrut: Dâiratü'l-Me'ârifi'l-'Usmâniyye-Dâru İhyâi't-Turâsi'l-'Arabî, 1952.

Sa 'īd b Manșūr, Ebû Osman Saîd b. Mansûr b. Şu'be el-Horasânî el-Cûzcânî. Sünenü Sa 'ìd b. Manșūr. thk. Habîburrahman el-A'zamî. 12 Cilt. Hindistan: ed-Dâru'sSelefiyye, 1982.

Safedî, Salâhuddin Halil b. Aybek b. Abdullah. el-Vâfî bi'l-vefeyât. thk. Ahmed el-Arnaût, Türkî Mustafa. 29 Cilt. Beyrut: Dâru İhyâi't-Turâs, 2000.

Sem'ânî, Ebû Sa'd Abdulkerim b. Muhammed b. Mansûr et-Temîmî el-Mervezî. elEnsâb. thk. Abdurrahman b. Yahya el-Muallimî el-Yemânî vd. 11 Cilt. Haydarabad: Meclisu Dâirati'l-Me'ârif el-'Usmaniyye, 1962.

Sıbt İbnü'l-Cevzî, Ebü'l-Muzaffer Şemsüddîn Yûsuf b. Kızoğlu et-Türkî el-Avnî elBağdâdî. Mir'âtü'z-zamân fî târîhi'l-a yân. thk. Muhammed Berekât vd. 23 Cilt. Dımaşk: Dâru'r-Risâleti'l-'Âlemiyye, 2013.

Süheylî, Ebu'l-Kâsım Abdurrahman b. Abdullah b. Ahmed. er-Ravżü'l-ünüf fi şerhi'sSîreti'n-nebeviyye li'bni Hişâm. thk. Ömer Abdusselam es-Selâmî. 7 Cilt. Beyrut: Dâru İhyâi't-Turâsi'l-'Arabî, 2000.

Şenel, Abdülkadir. "Selmân b. Rebîa”. Türkiye Diyanet Vakfi İslâm Ansiklopedisi. 36/443444. İstanbul: Türkiye Diyanet Vakfı Yayınları, 2009.

Taberî, Ebû Ca'fer Muhammed b. Cerîr. Târîhu'l-ümem ve'l-mülûk. 5 Cilt. Beyrut: Dâru'l-Kütübi'l-'İlmiyye, 1407.

Zehebî, Şemseddin Ebû Abdullah Muhammed b. Ahmed b. Osman b. Kaymâz. el- '̇̉ber fi haberi men ġaber. thk. Ebû Hacer Muhammed es-Saîd b. Besyûnî Zağlûl. 4 Cilt. Beyrut: Dâru'l-Kütübi'l-'İlmiyye, ts.

Zehebî, Şemsuddin Ebû Abdullah Muhammed b. Ahmed b. Osman b. Kâymâz. Târîhu'l-İslâm ve vefeyâtü'l-meşâhîr ve'l-a'lâm. thk. Ömer Abdüsselâm etTedmurî. Beyrut: Dâru'l-Kitabi'l-'Arabî, 2. Basım, 1993. 


\section{Salmān b. Rab̄̄'a's Life and Activities}

\section{(Extended Abstract)}

Salmān b. Rab̄̄'a, Abū Abdallāh, is from Kufa. Ibn Sa‘d (d. 230/845) mentions him in the first layer of the people of Kufa. Salmān b. Rabī'a is a poet and a good follower. In addition, he is a brave and devout hero. It is recorded that he participated in the battles for one year and went on pilgrimage for another year. The scholars disagreed on whether Salmān b. Rabīa was a companion or not. Some scholars adopt the view that he is a companion, while others say that he is a successor. Abū Nu'aym al-Ișfahānī (d. 430/1038) and Ibn al-Athīr (d. 630/1233) share the opinion that Salmān b. Rabī'a lived in the time of the Hazrat Prophet but did not have a conversation with the prophet. 'Ijli (d. 261/875) states that he is from successors. Ibn Manda (d. 395/1005) expresses the view that he is from successors. Khalīfa b. Khayyāț (d. 240/854-855) mentions it in the first layer of the successors. In addition, Khațīb al-Baghdādī (d. 463/1071) and Nawawī (d. 676/1277) are among the scholars who stated that he was a successor. On the other hand, Abū Hātim (d. 277/890) says that he is a companion. Ibn 'Abd al-Barr (d. 463/1071), 'Uqaylī (d. 322/934), Abū Ḥātim al-Rāzī, Ibn Abū Ḥātim (d. 327/938), Dhahabī (d. 748/1348), Șafadī (d. 764/1363) and Ibn H.ajar (d. 852/1449) stated that he was a companion. First of all, it should be stated that although there are opinions that Salmān b. Rabī'a narrated hadiths directly from the Hazrat Prophet, we could not find such an event in the sources. In addition, it is seen that most of the scholars who stated that he was a companion expressed this information with hesitation rather than expressing it in a definite language. Again, no source clearly states that he had met with the Hazrat Prophet. As a result, we believe that it would be more appropriate to accept that he was not a companion but a muhadram who lived in the time of the Prophet but did not chat with him, in accordance with the opinion of the majority. Salmān b. Rabī'a is a person who lived his life in many ways and has provided good services in different fields. Because, if the information about Salmān b. Rabīa's life is examined carefully, it is seen that his activities in judicial, military, and scientific fields come to the fore. It is stated in many Islamic historical sources that Salmān b. Rabī'a was appointed as the judge of Kufa by Hazrat 'Umar. Salmān b. Rabī'a also participated in the Qādisiyya War (15/636) during the time of Hazrat 'Umar and served as a military judge in the army. In addition, Mas' 'ùd̄̄ (d. 345/956) shares the information that he was a judge in Medina during the time of Hazrat 'Umar. In Islamic historical sources, it is mentioned that Salmān b. Rabī'a participated in the ghaza movements carried out against Damascus during the time of Hazrat 'Umar and then the Qādisiyya war. Salmān, who joined the war with his brother 'Abd al-Rahmān b. Rabī'a (d. 32/652) at the head of the cavalry, 
showed great heroism in this war. Salmān b. Rabī'a was among the soldiers of Abū 'Ubayda Ibn al-Jarrāh (d. 18/639), commanded the conquest activities in Aleppo and Antakya, and settled in the fortress of Kūrus, which will later be called his name. Heraclius, provoked by the people of jazira in 17/638-639, attacked the Muslims under the command of Abū 'Ubayda in Himș. At the end of his consultations, Abū 'Ubayda decided to take his opinion by writing a letter to Hazrat 'Umar. Hazrat 'Umar had an application that he gave importance in terms of war technique. Accordingly, he had possession of horsemen in various regions as a precaution. If needed, soldiers would come and ride these horses, and they would set out as a ready force until other people were prepared for war. In this context, Salmān b. Rabī'a was the commander of the unit that was held in Kufa and there were 4 thousand horses. For this reason, he was also named as Salmān al-Khayl. After Abū 'Ubayda's letter, Hazrat 'Umar sent a message to Sa'd and asked him to send Ka'kā' b. 'Amr (d. 40/660) to Himș as support. Another military activity that Salmān b. Rabī'a participated during the Hazrat 'Umar period was the conquest of Bāb al-Abwāb, which was carried out in 22/642-643. Hazrat 'Umar, who appointed 'Abd al-Rahmān b. Rabi' $\mathrm{a}$ as the commander of the pioneers of the soldiers sent here, appointed Bukayr b. Abdallāh (d. ?) and Hiudhayfa b. Asīd (d. 42/662) to the left and right wings of the army. He gave the task of distributing the spoils to Salmān b. Rabīa. Salmān continued his conquest activities with his brother 'Abd alRaḥmān during the period of Hazrat Uthmān, who passed into the caliphate after the death of Hazrat 'Umar. Salmān, who took the standard after 'Abd alRaḥmān b. Rabī'a was martyred during the raids on Turkish provinces, continued the struggles. Salmān carried out many important tasks in the conquest activities, and he was martyred together with 4 thousand Muslim soldiers in the war behind the Balanjar River. Apart from military activities, Salmān also served in the field of science and contributed to some narrations reaching us. It is stated in the sources that he did not narrate many hadiths. Salmān b. Rabī'a as a reliable person became someone trusted by hadith scholars. 